\title{
Specifics of Cryptocurrencies from an Accounting, Tax and Financial View in a Globalized Environment
}

\author{
Ivana Kucharova $^{1,}{ }^{*}$, Daniela Pfeiferova $^{1}$, and Enikö Lőrinczova ${ }^{1}$ \\ ${ }^{1}$ Czech University of Life Sciences, Faculty of Economics and Management, Department of Trade \\ and Finance, Kamycka 129, 16500 Praha 6 - Suchdol, Czech Republic
}

\begin{abstract}
.
Research background: With the advancing entrance of digital technologies into all areas of private and business life in the past 10 years a new digital asset referred to as virtual currency or cryptocurrency had been invented. This virtual currency is not yet regulated in most countries and there is a need to establish a legal framework for accounting, taxation and recording of financial transactions so the treatment of transactions with these digital assets is the same across the globalized environment, as different approaches may affect the decision-making of the management and investors or can alter the tax base for income tax purposes.

Purpose of the article: The aim of this paper is to compare and discuss the different possible approaches of recording and reporting of the virtual currencies for accounting and tax purposes and to compare the approaches among the Czech Republic, the Slovak Republic and Germany to point out the need for a harmonized solution in a global environment, as dealing with cryptocurrencies is not included in the accounting and tax legal framework in many other countries.

Methods: Methods of description, analysis, comparison and synthesis are used to achieve the set aim of the paper. Different approaches to the topic are demonstrated and compared in illustrative Tables.

Findings \& Value added: The paper highlights the need for a uniform approach for the accounting and tax treatment of virtual currency by comparing the level of legal definitions and different approaches. The most elaborate legal implementation of this topic is in the Slovak Republic where the treatment of virtual currencies is included in the Accounting Act and the Income Tax Act. The Czech Republic approaches cryptocurrencies only on the basis of recommendations from the Ministry of Finance, which is not legally binding to obey. Germany has included cryptocurrencies in the Banking Act, the accounting definition is missing and the tax solution is in the Income Tax Act.
\end{abstract}

${ }^{*}$ Corresponding author: kucharovai@pef.czu.cz 
Keywords: financial globalization; taxes; valuation; accounting; virtual assets

JEL Classification: $F 30 ; H 20 ; M 41$

\section{Introduction}

The name cryptocurrency or virtual currency may give the wrong impression that it is a new form of fait money, i.e. government-issued currency. The European Banking Authority (EBA) defined a virtual currency as a digital representation of value that is neither issued by a central bank or a public authority nor necessarily attached to a fiat currency, but is accepted by natural or legal persons as a means of payment, and can be transferred, stored or traded electronically [1]. Cryptocurrencies are virtual currencies created with cryptographic algorithms. The legislation approach regarding cryptocurrencies and virtual currency from an accounting, tax and financial view is not so clear-cut and simple. Although the first cryptocurrency, bitcoin (a blockchain-based cryptocurrency) originated in 2009 and is increasingly used on the market, the national legislation of different countries reacts with considerable delay. It is not easy to define a new asset that was created by computer mining, exists in intangible form and is stored in special virtual wallets.

Unlike traditional currencies whose legitimacy relies on political and legal mechanisms, cryptocurrencies according to [2], rely only on the cryptographic integrity of the network itself. Unlike other financial market products, they do not have their own value, which is able to generate regular income. The existence of cryptocurrencies as a specific financial asset also allows their inclusion in investment portfolios. According to [3] cryptocurrencies represent an alternative investment tool for risk diversification in the investment portfolio. The inclusion of bitcoins in traditional stock and bond portfolios is also analyzed in their study by [4].

Many cryptocurrencies operate as blockchain-based decentralized systems. Blockchain technology has the potential to change and shape the nature of today's accounting. It can be a way to significantly automate accounting processes in accordance with regulatory requirements. Another major audit firm, [5], predicts a promising future for the use of blockchain technology in accounting, as instead of separate accounting transactions, companies can enter their transactions directly to a common register, creating an interconnected system of permanent accounting records. Such a method would make it possible to verify the data relating to the financial statements automatically and the costs and time to carry out the audit would be significantly reduced.

Since 2009 , blockchain has served as a potentially transformative information technology that should be as revolutionary as the Internet. The blockchain function, originally developed as a methodology for recording cryptocurrency transactions, has evolved into a large number of applications, such as banking, financial markets, insurance, voting systems, leasing contracts and government services. Despite this progress, the application of the blockchain in accounting and assurance remains insufficiently explored. There are also new areas with the application of bitcoins with a unique blockchain DLCC (Digital Learning Chain Structure) with which an automated payment system could be created at universities, supervision of student scholarships, when the system reads study results and sends the required amount of cryptocurrency if conditions are met. from a university account to a student account [6]. Another of the contributions by [7] clarifies the use of blockchain technology in financial accounting and its possible implications. The authors state that in the short term, a public blockchain could be used as a platform for companies to voluntarily disclose their information. In the long run, the application could effectively reduce errors in 
disclosure and revenue management, increase the quality of accounting information, and reduce information asymmetries.

Cryptocurrencies are seen as a possible future commodity identical to money, which is convertible, relatively stable and liquid [8]. The electronic information obtained from the hybrid communication system is the basis for fully automated documentation, creation of accounting records, information of accountants and management of non-cash transfers. The automation of managerial accounting through electronic transactions helps to increase the level of internal and external control over the execution of monetary operations through timely and remote sharing of information on payment parameters [9].

Cryptocurrencies involved in the money laundering process is dealt with by [10]. The results of the study showed that cryptocurrency is a suitable tool for money laundering because it provides the currency owner with relative anonymity because it does not require any personal information about the user and his location. These circumstances cause difficulties in criminal investigations of cryptocurrency money laundering, thus minimizing the ability of law enforcement authorities to monitor and identify crime. Cryptocurrency transactions are beyond government control because any cryptocurrency transactions do not require verification by third parties, such as a bank, government agency, or non-governmental organization. A cryptocurrency user can have more than one account and perform transactions from different locations at the same time. Contrary to the above views [10], other findings of [11] show that cryptocurrencies do not behave like traditional currencies or commodities and represent a sector that is much more advanced and less speculative.

How a blockchain could enable a real, verifiable and transparent accounting ecosystem is discussed by [12]. According to this author, the blockchain has the potential to transform current audit procedures, which would contribute to a more accurate and timely automatic system of verification. The methodology of collecting accounting information on settlement with cryptocurrencies and other electronic money without creating traditional payment documents and bank statements, where electronic information from a hybrid communication system is the basis for fully automated accounting documentation, accounting and managing cashless transfers is also documented by [9]. The automation of managerial accounting of electronic transactions helps to increase the level of internal and external control over the execution of monetary operations through timely and remote sharing of information on payment parameters.

Accounting professionals will need to be able to deal with new emerging business issues, like for example recording bitcoin operations (or cryptocurrency in general). There is potential for creating new opportunities for motivated professionals to offer consulting services related to dealing with various types of cryptocurrencies or to perform the role of a professional technology consultant related to accounting and auditing [13].

The current new era of accounting is conditioned by rapid technological development and the introduction of robotics. The activities of accountants gradually change over time. Robots already allow invoice data to be automatically extracted into accounting programs and processed seven days a week for 24 hours, moving accountants to a higher level for more professional work. Both accountants and auditors will be subject to higher requirements for accounting training. For a proper accounting approach to virtual currencies, it will also be necessary to understand the technologies and links, how virtual currencies are created, how they are proven and verified or inventoried. The new technology has a significant impact on the world of finance and accounting. In response to the growing adoption of blockchain, EY [14] has developed the Blockchain Analyzer platform, which as an auditor provides clients with increased transparency in these transactions. 


\section{Material and Methods}

In a globalized economy, the likelihood that an accountant or auditor will encounter the problem of how to measure, assess, record and correctly report virtual currency in their financial statements is becoming increasingly common. Our motivation to perform this comparative analysis was based on the need to highlight the different approaches related to the accounting and tax issues of virtual currencies in selected countries to the professional public and the academics. Different countries set their own legal requirements, internal processes and recommendations related to cryptocurrencies. The aim of this paper is to document, analyze, interpret, compare and point out the differences between the accounting and tax models regarding cryptocurrencies in the Czech Republic, Slovakia and Germany. The paper uses a descriptive research method for the characteristics and concept of virtual currencies, which is based on the study of legal regulations (especially the Accounting Act, VAT Act, Income Tax Act) and recommendations issued by ministries and other responsible bodies, followed by the comparison of the information obtained and its evaluation. The information was collected mainly from professional scientific articles, professional literature, legislative standards and websites that deal with the issue of cryptocurrencies.

The paper does not deal with the technological side of cryptocurrencies.

\section{Results and Discussion}

Cryptocurrencies are getting increasingly involved in the dealings of the business environment. The number of shops accepting cryptocurrencies as means of payment is increasing. There are also ways to invest in funds using cryptocurrencies. Both the accounting and auditing profession need to respond to the conditions of these changing practices.

Table 1. Shops accepting cryptocurrency as a payment (August 2020).

\begin{tabular}{|c|c|c|}
\hline Country & $\begin{array}{c}\text { Number of shops accepting } \\
\text { payments in cryptocurrency }\end{array}$ & $\begin{array}{c}\text { Number of habitants } \\
\text { per shop }\end{array}$ \\
\hline Slovenia & 542 & 3,839 \\
\hline The Czech Republic & 324 & 32,993 \\
\hline Switzerland & 155 & 55,290 \\
\hline The Netherlands & 261 & 66,206 \\
\hline The Slovak Republic & 69 & 79,101 \\
\hline Germany & 283 & 293,356 \\
\hline
\end{tabular}

Source: own processing and calculations based on [15]

As can be seen in Table 1, there are a total of 324 stores in the Czech Republic, where it is possible to pay by cryptocurrency in 2020. This is a share of 32,993 inhabitants per shop. Furthermore, the data show that the most progressive country is Slovenia, with a network of 542 stores with a population of 3,893 inhabitants per such store. Of the selected countries, Germany has the least density network of stores. Cryptocurrencies are also gaining in importance in the field of finance. Cryptocurrencies worth of CZK 3 billion were traded in the Czech Republic in years 2018 and 2019, each [16].

There are possibilities of using cryptocurrencies in business activities in the Czech Republic in the area of speculation or the use of cryptocurrencies as a means of payment [17]. The increased use of cryptocurrencies in practice forces the setting of accounting, tax and legal approaches to this type of currencies. Based on the analysis of available information 
on the definition of cryptocurrencies in the Czech Republic, Slovak Republic and Germany, these results will be compared in the end.

\subsection{The Czech Republic}

There is no uniform legal definition and a specific method of recording and reporting of digital currencies in the Czech Republic. The opinions and recommendations of the Czech

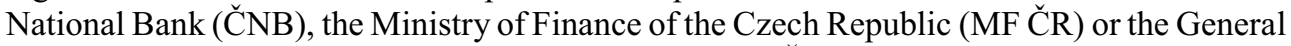
Finance Directorate has to be used. According to the ČNB [18], cryptocurrencies are not official currency, are not non-cash or electronic money and do not constitute a payment service or a non-cash transaction. Bitcoin is not an investment financial instrument because its nature does not meet the characteristics of a security or financial derivative pursuant to Section 3 of the Capital Market Business Act (Act No. 256/2004 Coll.). The Ministry of Finance of the Czech Republic issued an opinion in 2018 [19], according to which, despite various motives for holding and use, digital currencies are an asset and recommends that they be reported in the balance sheet as "special" intangible inventories separately from other inventories. Information on their acquisition, intent of keeping, valuation and inventorytaking, e.g. by virtual wallet, is to be provided in the notes to the financial statements. This recommendation defined a completely new current intangible asset in the Czech accounting environment. In the case of mining, new cryptocurrencies are valued at the price of the incurred own costs, in case of purchase they are valued at the acquisition price. The decrease (disposal) of digital currencies is to be valued using the FIFO method or the weighted arithmetic average according to the Decree 500/2002 Coll.

For VAT purposes the EU approach is used which is based on the judgment of the Court of Justice of the EU (CJE), case C-264/14 Hedqvist of 2015, where the exchange of a virtual currency for another virtual currency or fiat currency is considered a tax-exempt financial activity without the right to claim. Payments made by cryptocurrency for the supply of goods or services are exempt from VAT provided that the cryptocurrency serves as a means of payment. The sale of goods and services itself is taxed. Payments by bitcoin for services does not mean that the actual service provided is not taxable. The mining of cryptocurrencies is not resolved by the VAT Act No 235/2004 Coll. and there are conflicting views on whether or not it should be subject to VAT. The Income Tax Act No. 586/1992 Coll. classifies income from mining as a taxed income for natural persons who perform self-employed activity according to $\S 7$ of this Act. Trading with cryptocurrencies is subject to the obligation to hold a trade license. When trading in digital currencies, income is taxed according to $\S 7$ (or $\S 10$ as other income in the case that it is an occasional activity and not a regular business activity). The exchange of a cryptocurrency for another cryptocurrency or for other services or goods is also subject to income tax. Ownership of cryptocurrencies is tax neutral so a possession of cryptocurrencies is not subject to income tax.

\subsection{The Slovak Republic}

Short-term current financial assets are defined in the Accounting Act No. 431/2002 Coll. in $\S 17$ par. 10 let. c). as assets recorded in the account group 25 , including the virtual currency acquired for consideration, the virtual currency acquired by mining on the date of exchange for another asset or service, and the virtual currency acquired in exchange for another virtual currency. Thus, virtual currencies are clearly defined and have their exact place among the balance sheet items. Virtual currency acquired by mining is recorded first on off-balance sheet accounts and only at the moment of exchange for another asset or service is it measured at fair value in EUR. The purchase and exchange of cryptocurrencies is treated as the other current financial assets are treated and is measured at fair value at the moment of acquisition. 
This value is determined as the market price on the day of the accounting event, e.g. as the aggregation of stock exchange prices. Analytical sub-ledger accounts are established for individual types of cryptocurrencies. The FIFO method or the weighted arithmetic average is used for disposals of these assets. Exchange differences are recognized as financial expenses of financial revenues. For the purposes of the income tax, the regulations are not as much specific as in the case of accounting regulations. Similar to the Czech Republic, it is necessary to determine the origin of the virtual currency, i.e. whether it was created by mining or purchasing. Contrary to the accounting practice, the purchased cryptocurrency has to be valued at cost and not at fair value for the income tax purposes. Any difference arising in valuation has to be reflected in the tax return. According to the Income Tax Act No. 595/2003, ( $\$ 19$ par. 2 let.v), it is not possible to claim a tax loss from the sale of cryptocurrencies. The VAT treatment for cryptocurrencies is based on the ECJ Hedqvist judgment of 2015 and is identical to the treatment in the Czech Republic.

\subsection{Germany}

The issue of cryptocurrencies is regulated by the Banking Act (Kreditwesengesetz KWG). The Federal Office for Financial Supervision [20] issued information on cryptocurrency transactions on 2.3.2020. It states that the Act on Banks in $\S 1$ a) par. 6 includes the safekeeping, administration and security of cryptographic values or private cryptographic keys (which are used to store or transfer cryptographic values for others) in the financial activities and among the financial services of banks. The cryptocurrencies are thus considered a financial instrument. Trading with cryptocurrencies was included as a new financial service in the German Banking Act. From 1.1.2020, companies and financial intermediaries that offer or wish to offer cryptocurrency trading in the future must obtain a license from the Federal Office for Financial Supervision. The application deadline is November 2020.

For accounting purposes, cryptocurrencies are not defined in any legislation. According to a discussion by [21], in order to include cryptocurrencies in assets, it is necessary to accurately identify the purpose of their creation or method of acquisition. Accordingly, they may be included in the balance sheet as current assets (in Other assets), or in long-term financial assets. New items such as long-term or short-term digital means of payment would be created for cryptocurrencies in the balance sheet structure in the future. The valuation of cryptocurrencies is carried out in accordance with the German Commercial Code at acquisition cost or at incurred own cost. For the decrease (disposals) of cryptocurrencies the LIFO, FIFO or weighted arithmetic average methods may be used. For income tax purposes the possession of a cryptocurrency is not subject to taxation. Income tax is applied on payments in cryptocurrency if the purchase of goods and services occur. When trading cryptocurrencies, the positive difference between the sale price and the costs incurred to acquire the cryptocurrency is taxed. Profits up to EUR 600 are exempt from tax. If the period between the acquisition and sale of the cryptocurrency has exceeded one year, the income is exempt from personal income tax. The mining of cryptocurrencies is considered as a creation of an asset by business activity and is taxed the same as the production of other economic goods [22]. Value added tax is regulated in the same way as in the Czech Republic according to the ECJ judgment in the Hedquist case. The mining of cryptocurrencies is classified as an activity not subject to VAT, because there is no individually determined recipient of the service and thus the essence of VAT is not fulfilled.

\subsection{Comparison of accounting and tax regulations regarding cryptocurrency}

According to the analyzed regulations it is clear that the legal regulations are set at different levels in individual countries. The most advanced of the selected countries related to legal 
definitions of virtual currency is the Slovak Republic where there is precisely defined in the Accounting Act when virtual currencies are recognized, including the need of their analytical sub-ledger registration, and methods of valuation and reporting. For the time being, the Federal Republic of Germany has incorporated virtual currencies only into the Banking Act, according to which it considers them to be a financial instrument and a financial service. Accounting regulations do not have virtual currencies defined in Germany and their accounting treatment can only be derived from the opinions of academics or other experts, e.g. from accounting and tax advisers. In the Czech Republic the Ministry of Finance only issued recommendations on how to deal with cryptocurrencies and a new term was introduced for it: current intangible assets - inventories.

Table 2. Comparison of the accounting treatment regarding cryptocurrencies.

\begin{tabular}{|c|c|c|c|}
\hline & The Czech Republic & $\begin{array}{l}\text { The Slovak } \\
\text { republic }\end{array}$ & Germany \\
\hline Type of asset & $\begin{array}{l}\text { Current intangible } \\
\text { inventory }\end{array}$ & $\begin{array}{l}\text { Current financial } \\
\text { asset }\end{array}$ & $\begin{array}{c}\text { Non-current } \\
\text { financial assets or } \\
\text { current Other assets }\end{array}$ \\
\hline Valuation at mining & Incurred own costs & Fair value & Incurred own costs \\
\hline $\begin{array}{c}\text { Valuation at purchase } \\
\text { or exchange }\end{array}$ & Acquisition cost & Fair value & Acquisition cost \\
\hline Valuation for disposals & $\begin{array}{c}\text { FIFO; } \\
\text { weighted arithmetic } \\
\text { average }\end{array}$ & $\begin{array}{c}\text { FIFO; } \\
\text { weighted arithmetic } \\
\text { average }\end{array}$ & $\begin{array}{c}\text { FIFO; LIFO; } \\
\text { weighted arithmetic } \\
\text { average }\end{array}$ \\
\hline
\end{tabular}

Source: own processing

Cryptocurrencies are subject to income tax in the analyzed countries in varying conditions. In some cases, the tax legal framework is not specific enough for both natural and legal persons. Table 3 shows the terms of tax treatment which can be set differently depending on the country.

Table 3. Comparison of the income tax treatment regarding cryptocurrencies.

\begin{tabular}{|c|c|c|c|}
\hline $\begin{array}{c}\text { The Czech } \\
\text { Republic }\end{array}$ & $\begin{array}{c}\text { The Slovak } \\
\text { Republic }\end{array}$ & Germany \\
\hline $\begin{array}{c}\text { Subject to taxation in case of } \\
\text { purchase, exchange for other } \\
\text { cryptocurrency or payment } \\
\text { made by cryptocurrency for } \\
\text { goods or services }\end{array}$ & Yes & Yes & Yes \\
\hline $\begin{array}{c}\text { Subject to taxation in case of } \\
\text { possession }\end{array}$ & No & No & No \\
\hline $\begin{array}{c}\text { Subject to taxation in case of } \\
\text { mining }\end{array}$ & Yes & Yes & Yes \\
\hline $\begin{array}{c}\text { Tax exemption } \\
\text { No }\end{array}$ & No & $\begin{array}{c}\text { Non-entrepreneurial } \\
\text { natural person - YES } \\
\text { (after 1 year of holding) } \\
\text { Entrepreneurial natual or } \\
\text { legal person - NO }\end{array}$ \\
\hline $\begin{array}{c}\text { Expenses recognized for tax } \\
\text { purposes at entrepreneurs }\end{array}$ & Yes & $\begin{array}{c}\text { Yes } \\
\text { (but not } \\
\text { possible to } \\
\text { aply a tax loss } \\
\text { neither for }\end{array}$ & Yes \\
\hline
\end{tabular}




\begin{tabular}{|l|l|l|l|}
\hline & & $\begin{array}{c}\text { natural nor for } \\
\text { legal person) }\end{array}$ & \\
\hline
\end{tabular}

Source: own processing

The most significant difference in taxation is that in Germany there is a possibility for natural persons who are not entrepreneurs to exempt income from cryptocurrencies after one year's holding from taxation. If the holding period does not exceed one year, only the income up to EUR 600 can be exempted. If the income exceeds this limit, the entire income is subject to taxation, not only the amount above EUR 600. In all jurisdictions, it is necessary to determine exactly whether the mining is operated as a business, i.e. a continuous activity or it is only occasional. Entrepreneurial activity is subject to the principles of taxation of business income; casual activity is taxed as other income. The least favorable tax conditions are set in the Slovak Republic, where it is not possible to claim a tax loss from cryptocurrencies. From a VAT point of view, all three jurisdictions treat cryptocurrencies in the same way.

\section{Conclusions}

This paper compares the legal framework related to cryptocurrencies with focus on the accounting and tax treatment in the Czech Republic, the Slovak Republic and the Federal Republic of Germany. The status of cryptocurrencies is implemented into the legislation at various levels in these countries. The most elaborate legal implementation of this topic is in the Slovak Republic where the treatment of virtual currencies is included in the Accounting Act and the Income Tax Act. The Czech Republic approaches cryptocurrencies only on the basis of recommendations from the Ministry of Finance, which is not legally binding to obey. Germany has included cryptocurrencies in the Banking Act, the accounting definition is missing and the tax solution is in the Income Tax Act.

It is very important that there is a unified European or global definition of virtual currencies and cryptocurrencies. In many countries, the legal framework for cryptocurrencies is not considered at all and needs to be developed [23]. Cryptocurrencies are gaining significant popularity due to the benefits of their use, such as convenience, independence, accessibility, lack of commitment, confidentiality, no documents, full accounting automation, and optimization of administrative costs [24]. There are also ways to invest in funds using cryptocurrencies.

On the basis of the comparison carried out in our paper and the results gained we agree with the conclusions of other published authors, cited in the paper.

Our future research is focused on the practical approaches how natural and legal persons deal with the accounting and tax side of cryptocurrencies in practice.

This paper is a partial result of the research project No. 2019B0010 - Czech Social System Fraud Rate Estimation and System Optimization Proposals, supported by the Internal Grant Agency (IGA) of Faculty of Economics and Management, CULS Prague.

\section{References}

1. European Parliament. (2016). European parliament resolution of 26 May 2016 on virtual currencies. Retrieved from: https://www.europarl.europa.eu/doceo/document/TA-8-2016-0228_CS.html.

2. Andrada-Felix, J., Fernandez-Perez, A., Sosvilla-Rivero, S. (2020). Distant or close cousins: Connectedness between cryptocurrencies and traditional currencies volatilities. Journal of International Financial Markets Institutions \& Money, 67(6), 101219. 
3. Guesmi, K., Saadi, S., Abid, I., Ftiti, Z. (2019). Portfolio diversification with virtual currency: Evidence from bitcoin. International Review of Financial Analysis, 63(5), 431-437.

4. Platanakis, E., Urquhart, A. (2020). Should investors include bitcoin in their portfolios? A portfolio theory approach. The British Accounting Review, 52(4).

5. Deloitte. (2016). Blockchain technology a game-changerin accounting? Retrieved from:

https://www2.deloitte.com/content/dam/Deloitte/de/Documents/Innovation/Blockchai n_A\%20game-changer\%20in\%20accounting.pdf.

6. Balint, K., Cvetkovic, D., Takacs, M., Holik, I., Toth, A. (2019). Connecting bitcoin blockchain with digital learning chain structure in education. Acta Polytechnica Hungarica, 16(1), 77-96.

7. Yu, T., Lin, Z., Tang, Q. (2019). Blockchain: The introduction and its application in financial accounting. The Journal of Corporate Accounting \& Finance, 29(4), 37-47.

8. Sadil, V. (2018). Phenomenon bitcoin: Money of future or junk commodity? Proceedings of the 14th Annual International Bata Conference (pp. 219-228). Zlín: Tomas Bata University in Zlín.

9. Zadorozhnyi, Z.-M. V., Muravskyi, V. V., Shevchuk, O. A. (2018). Management accounting of electronic transactions with the use of cryptocurrencies. Financial And Credit Activity: Problems Of Theory And Practice, 3(26), 169-177.

10. Dyntu, V., Dykyi, O. (2019). Cryptocurrency in the system of money laundering. Baltic Journal of Economic Studies, 4(5), 75-81.

11. Wang, S., Vergne, J.-P., Podobnik, B. (2017). Buzz factor or innovation potential: what explains cryptocurrencies' returns? PLoS ONE, 12(1), e0169556.

12. Dai, J., Vasarhelyi, M. A. (2017). Toward blockchain-based accounting and assurance. Journal of Information Systems, 31(3), 5-21.

13. Smith, S. S. (2018). Implications of next step blockchain applications for accounting and legal practitioners: A case study. Australasian Accounting, Business and Finance Journal, 12(4), 77-90.

14. EY. (2020) How to audit the next generation of digital assets. Retrieved from: https://www.ey.com/en_gl/assurance/how-to-audit-the-next-generation-of-digitalassets

15. Coinmap. (2020) All the cryptocurrency merchants and ATMs of the world in one map. Retrieved from: www.coinmap.com

16. Novinky. Cz. (2019). V Česku se letos uskuteční obchody s kryptoměnami za tři miliardy. Retrieved from: https://www.novinky.cz/internet-a-pc/clanek/v-cesku-seletos-uskutecni-obchody-s-kryptomenami-za-tri-miliardy-40305590.

17. Kolkova, A. (2018). The use of cryptocurrency in enterprises in Czech Republic. Proceedings of the 6th International Conference on Innovation Management, Entrepreneurship and Sustainability (pp. 541-552). Prague: Univ Econ.

18. Vodrazka, M. (2014). Obchodování s bitcoiny [Online]. Retrieved August 27, 2020, from https://www.cnb.cz/export/sites/cnb/cs/casto-kladenedotazy/.galleries/stanoviska_a_odpovedi/pdf/obchodovani_s_bitcoiny.pdf

19. MF ČR. (2018). Sdělení Ministerstva financí k účtování a vykazování digitálních měn. Retrieved from https://www.mfcr.cz/cs/verejny-sektor/ucetnictvi-a-ucetnictvistatu/ucetnictvi-podnikatelu-a-neziskoveho-sek/aktuality-a-metodickapodpora/2018/sdeleni-ministerstva-financi-k-uctovani-31864. 
20. BaFin. (2020). Bundesanstalt für Finanzdienstleistungsaufsicht Suchtext, Retrieved from: bafin.de.

21. Hollidt, A. (2019). Der Ausweis von Kryptowährungen im Jahresabschluss unter Anwendung der Grundsätze ordnungsmäßiger Buchführung und Bilanzierung Retrieved from: https://www.researchgate.net/publication/333893447_Der_Ausweis_von_Kryptowahr ungen_im_Jahresabschluss_unter_Anwendung_der_Ğ Grundsatze_ord̄nungsmassiger_B uchfuh-_rung_und_Bilanzierung. Diskussionpapier. Hochschule Mittweida University of Applied Sciences.

22. Winhller. (2020). Winheller: Rechtsanwählte\&Steuerberrater. Retrieved from: www.winheller.com.

23. Chudinovskikh M., Sevryugin V. (2019). Cryptocurrency regulation in the BriCs Countries and the Eurasian economic union. BRICS Law Journal, 6(1), 63-81.

24. Bondarenko, O., Kichuk, O., Antonov, A. (2019). The possibilities of using investment tools based on cryptocurrency in the developmet of the national economy. Baltic Journal of Economic Studies, 5(2), 10-17. 